\title{
Household Solid Waste Characteristics and Management in Rural Communities
}

\author{
Paúl Taboada-González ${ }^{*},{ }^{1}$, Carolina Armijo-de-Vega ${ }^{2}$, Quetzalli Aguilar-Virgen ${ }^{1}$ and \\ Sara Ojeda-Benítez ${ }^{3}$
}

\author{
${ }^{I}$ Doctoral Degree Students of the Program Master's Degree and Doctoral Degree in Sciences and Engineering of the \\ Autonomous University of Baja California, Mexico \\ ${ }^{2}$ Ensenada Faculty of Engineering, Autonomous University of Baja California, Tijuana-Ensenada Highway, $103 \mathrm{~km}$ \\ south of Tijuana, Ensenada, 22870 Baja California, Mexico \\ ${ }^{3}$ Institute of Engineering, Autonomous University of Baja California, Benito Juárez Blvd. and De la Norma St., Mexicali, \\ 21280 Baja California, Mexico
}

\begin{abstract}
Globally there is a lack of knowledge about waste generation and composition in rural areas because these types of studies have been conducted mainly in big cities. This leaves the local sanitation authorities without information to properly plan its operations. Generally, characterization studies are carried out by using the technique of sampling taking at home level. This method requires human, material and economic resources that sometimes are limited for local sanitation authorities. This paper presents the results of a characterization study obtained by direct analysis of household solid waste generated in two rural communities in northern Mexico. The research also outlines a procedure for estimating the waste generation rate when financial constraints prevent the development of a characterization study at home level. This study attempts to fill the information gap on the generation and composition of solid waste in rural areas. The results indicate a waste generation of $0.631 \mathrm{~kg} / \mathrm{cap} /$ day in San Quintín and $1.047 \mathrm{~kg} / \mathrm{cap} /$ day in Vicente Guerrero. The specific weights of the uncompacted SW were respectively $145 \mathrm{~kg} / \mathrm{m}^{3}$ and $123 \mathrm{~kg} / \mathrm{m}^{3}$. The specific weight of the compacted SW was $229 \mathrm{~kg} / \mathrm{m}^{3}$ in San Quintín. Statistically, the composition of waste between these two rural communities differs in one fraction.
\end{abstract}

Keywords: Characterization, solid waste, rural communities, waste composition, waste generation.

\section{INTRODUCTION}

Solid waste (SW) constitutes a huge challenge for local governments due to its constant increase and the majority of the municipalities do not keep records on waste generation, origin and characteristics. This lack of information causes that the decisions regarding proper waste management are based on assumptions and inferences, which brings about its mishandling with serious consequences for the environment [1]. Examples thereof are river and groundwater contamination by landfill leachates, soil pollution, greenhouse gas emissions and fauna mortality.

It is necessary to know the intrinsic qualitative and quantitative characteristics of $\mathrm{SW}$ as its increase demands alternatives of handling and treatment [2]. The studies of characterization may include analysis such as: physical and chemical composition, volume and generation that provide information for the planning and management of waste for its beneficial use and final disposal. Therefore, these studies constitute the first step to successfully implementing a comprehensive waste management system $[1,3,4]$.

The results of the studies of characterization cannot be generalized towards different regions and seasons of the year

*Address correspondence to this author at the Engineering Institute, Autonomous University of Baja California, Mexico; Tel: 52 (686) 5664150; E-mail: taboadapa@gmail.com because there are many variants such as: eating habits, consumption patterns, population composition, season of the year and income, that can cause dramatic changes in the composition and generation of waste [1, 4-9].

Some studies of characterization have been carried out in Mexico [3, 7, 10-17], but mostly in cities. This could affect the way parameters are being estimated in rural zones by researchers, who run the risk of generalizing a behavior and overestimating due to the lack of data [14].

Economic constraints and the lack of information on waste generation in San Quintín and Vicente Guerrero, two rural communities in Ensenada, Mexico have caused a poor management of solid waste. The insufficiency of the waste collection system causes that the residents incinerate or discard the waste in sites near their homes. Similar situations have been reported in other rural communities of México, such as Santa Elena Canyon in Chihuahua [12] and Tulum in Quintana Roo [18]. In the latter was found that $86 \%$ of the residents use the municipal solid waste collection service, $8 \%$ burn the waste, and $3 \%$ dump it in the rainforest or alongside the highway.

In the studied communities, the waste collected by the municipality is disposed of in non-controlled dumpsites and incinerated outdoors, even though Federal and State laws prohibit such practices, and hence it is not possible to find large volumes and dimension the problem. Ojolo and 
Bamgboye [19] explain that most of the waste on landfills sites or in other dumping sites is usually incinerated.

In view of this, it was decided to carry out a study whose purposes were the following: a) to analyze and quantify the solid waste generated in two rural communities: San Quintín and Vicente Guerrero in Ensenada, Baja California, Mexico; b) generate information for the decision-making in programs about waste management and environmental education; and c) create a benchmark for further studies of characterization.

\section{DESCRIPTION OF THE STUDY SITE}

The towns of San Quintín and Vicente Guerrero belong to the municipality of Ensenada, Baja California, Mexico. They are located $195 \mathrm{~km}$ and $170 \mathrm{~km}$ south of the municipal seat, respectively, and 30 meters above sea level (m.a.s.l.). The main economic activity in these communities is the agricultural production of vegetables and flowers. The agricultural activity brings about a floating or migrant population that fluctuates depending on the season of the year and work quantity on the farms. The origins of this population are mainly from Oaxaca, Michoacán, and Sinaloa $[20,21]$.

As far as the climate is concerned, the annual average temperature is $17{ }^{\circ} \mathrm{C}$, August being the hottest month of the year with an average temperature of $21^{\circ} \mathrm{C}$ and February the coldest month with an average temperature of $14^{\circ} \mathrm{C}$. The region's total annual precipitation ranges from $100 \mathrm{~mm}$ to $200 \mathrm{~mm}$, December with $24.2 \mathrm{~mm}$ and January with 23.9 $\mathrm{mm}$ being the wettest months, and May with $0.5 \mathrm{~mm}$ and June with $0.1 \mathrm{~mm}$ being the driest months [21].

San Quintín's dumpsite is located at $+30^{\circ} 31^{\prime} 24.45^{\prime \prime}$, $115^{\circ} 53^{\prime} 40.26^{\prime \prime} ; 3 \mathrm{~km}$ east of the town of Lázaro Cárdenas and sits on a 20-hectare ejido lot on a plateau close to Agua Chiquita Creek and a gorge. Vicente Guerrero's dumpsite is located at $+30^{\circ} 42^{\prime} 43.58^{\prime \prime},-115^{\circ} 58^{\prime} 24.00^{\prime \prime} ; 3 \mathrm{~km}$ east of Transpeninsular Highway and sits on a two-hectare private lot.

Waste collection is provided by the municipality, at no charge, and is not under concession in any stage of its process. The waste is collected at the curb, non-mechanized, once a week in one single shift. Residents are responsible for placing their garbage in bins at the curb on collection day and remove them once they have been emptied until the next collection day.

The waste collection vehicle fleet consists of wastecompacting rear loaders, and each one is operated by one driver and two waste collectors. Five collection vehicles with a capacity of $15.3 \mathrm{~m}^{3}\left(20 \mathrm{yd}^{3}\right)$ each and one with $19.11 \mathrm{~m}^{3}$ $\left(25 \mathrm{yd}^{3}\right)$ provide collection service in San Quintín, whereas only two vehicles with a capacity of $15.3 \mathrm{~m}^{3}\left(20 \mathrm{yd}^{3}\right)$ each provide collection service in Vicente Guerrero. The average age of all of these vehicles is 10 years old and their mechanical conditions are good.

\section{MATERIALS AND METHODS}

To determine the need for stratified sampling, socioeconomic statuses were identified by taking the Basic Geostatistical Area (BGA) as a reference, through the database "Composition of stratification-BGA, 2005" [22], provided by the National Institute of Statistics, Geography, and Data Processing,. It was observed that out of the 13 BGAs considered for San Quintín, the $89 \%$ has level between 5 and 3. This same percent prevails in Vicente Guerrero for the nine BGAs considered. Therefore, due to the BGAs composition in these communities generally maintain a single socioeconomic status (median-low), it was decided to take a non-stratified sampling. Additionally, the waste collection trucks do not follow routes established by socioeconomic status.

The study was carried out in January, 2009, during a week in the dumpsites of Vicente Guerrero and San Quintín. The population considered to estimate the per capita generation was 10,632 for the first community and 19,800 for the second one. This last value includes the residents of Lázaro Cárdenas, whose waste is disposed of at San Quintín's dumpsite.

Daily samples were taken from the waste unloaded by the waste collection vehicles. Representative samplings of household waste could be: a) a truck load coming from a typical weekday collection route from a residential area, b) a mixed sampling taken from an incinerator storage pit, and c) a discharge pit of a shredder [23].

In order to draw a representative sampling in each site, the wastes daily analyzed were taken from a single waste collection truck. None of the samples were left out because the waste generated in these communities is collected once a week, and it was considered that they were representative of the generation of seven days.

Tchobanoglous et al. [23] explain that the measurements made in a 90-kg sampling do not change significantly from the ones made in samplings of up to $770 \mathrm{~kg}$, taken out of the same waste load. CalRecovery [24] explains that the minimum weight per sample must be $100 \mathrm{~kg}$; if it is less than $100 \mathrm{~kg}$, the possibility of obtaining a representative sample reduces. Other authors establish that the optimum size of the sample ranges from $91 \mathrm{~kg}$ to $136 \mathrm{~kg}$ [25-28]. However, the Mexican Standard NMX-AA-015-1985 [29] indicates that a minimum of $50 \mathrm{~kg}$ of solid waste must be employed for the waste composition analysis. Therefore, to ensure representative results according to Mexican regulations, samples with a weight higher than $50 \mathrm{~kg}$ were taken.

\section{Waste Generation Estimation}

\section{Determination of the Specific Weight of the Wastes}

The specific weight of the un-compacted waste was determined following the procedure indicated by the Mexican Standard NMX-AA-019-1985 [30]. Waste from the loads disposed of by the waste collection trucks were placed in a container with a capacity of $0.2 \mathrm{~m}^{3}$ to fill it, the container was slightly slammed against the ground three times by dropping it from an approximate height of $10 \mathrm{~cm}$ and again more waste were added to fill it. The procedure continued until it got completely full. No pressure was applied to the waste in the container to avoid altering the specific weight. The net weight of the wastes (gross weighttare) was divided by the volume of the container.

The specific weight of the compacted waste was obtained by dividing the net weight of the waste by its capacity in $\mathrm{m}^{3}$. Since only the garbage trucks of San Quintín were weighed, 
the specific weight found in this study corresponds to this community.

\section{Determination of the Weight of the Wastes Disposed of at the Landfills}

The existence of a public scale in San Quintín allowed the waste collection trucks to be weighed before and after discarding the wastes in the landfill site for final disposal. The difference between the gross weight and the tare of the truck was considered as the net weight.

It was not possible to weigh the waste collection vehicles in Vicente Guerrero due to three factors: a) there is no public scale in this community and the closest one is $25 \mathrm{~km}$ away; b) the time to waste collection is limited; and c) the operating costs of transporting the waste are high, so the total weight of the wastes was estimated by using the equation (1):

$W_{T}=\left[\sum_{i=1}^{d}\left(N_{i} \times v_{i} \times \rho_{i}\right)\right]\left(F_{c}\right)$

where $\mathrm{d}=$ number of days analyzed, $\mathrm{N}=$ number of trips of the waste collection trucks, $\mathrm{v}=$ average in $\mathrm{m}^{3}$ of the trucks, $\rho$ $=$ average specific weight of uncompacted waste, and $\mathrm{F}_{\mathrm{c}}=$ compaction factor.

The compaction factor used (1.77) to infer the total weight in Vicente Guerrero was the one determined for the trucks of San Quintín. This was obtained by isolating $F_{c}$ in the equation (1) and substituting in every variable the values found at the site. It was decided to use this factor because the operating conditions of the collection vehicles waste refuse body in both sites are similar.

\section{Determination of the Per Capita Generation}

The per capita waste generation in both communities was calculated by dividing the weight of the waste disposed of at the dumpsites $\left(W_{T}\right)$ by the studied population $(\mathrm{H})$ multiplied by seven days (equation 2 ).

$G_{p c}=\frac{W_{T}}{H \times 7}$

\section{Analysis of Waste Composition}

\section{Waste Quantification}

For the analysis of waste composition, 30 waste components were considered. 25 indicated in the Mexican Standard NMX-AA-022-1985 [31] and five more annexed in situ. These were aluminum, batteries, Tetra Pakpackaging, PET plastics and electronic waste (see Table 1).

These waste components were divided into three groups: organics, non-organics and miscellaneous. Afterwards, a new classification (recyclables) was made with the waste components that have the possibility of being marketable in the communities nearby in order to define the selling potential of the wastes.

The weight measurements were performed in situ with portable electronic scales. These were an EQB 50/100 Torrey with a capacity of up $50 \mathrm{~kg}$ and readability of $10 \mathrm{~g}$, and a 500/1000 Torrey L-EQM with a capacity of up $500 \mathrm{~kg}$ and readability of $100 \mathrm{~g}$. For more accurate results, the specific weights were determined on the L-EQM 500/1000 and the weight of the waste components in the EQB 50/100.
Table 1. Waste Components Considered in the Study

\begin{tabular}{|l|l|}
\hline Cotton & Non-ferrous material \\
\hline Aluminum & Paper \\
\hline Batteries & Disposable diaper \\
\hline Cardboard & PET plastic \\
\hline Leather & Rigid and film plastics \\
\hline Waxed cardboard packaging & Polyurethane \\
\hline Hard vegetable fiber (sclerenchyma) & Expanded polystyrene \\
\hline Synthetic fibers & Food residuals \\
\hline Bone & Yard trimmings \\
\hline Rubber & Fine residue \\
\hline Tin can & Electronic waste \\
\hline Crockery and ceramics & Tetra Pakpackaging \\
\hline Wood & Cloth rags \\
\hline Construction material & Colored glass \\
\hline Ferrous material & Transparent glass \\
\hline Source: Adaptation from [34]. &
\end{tabular}

\section{Differences in the Waste Composition}

To identify if there were significant differences between the ratios of the main fractions of waste (those higher than $7.5 \%$ ) from the two rural communities, the $Z$ statistic was used within a $98 \%$ confidence interval. The MINITAB ${ }^{\mathrm{TM}}$ 14.1 statistical software was used to compare the ratios.

\section{RESULTS}

\section{Per Capita Generation and Specific Weight}

The waste generation per person per day was estimated in $0.631 \mathrm{~kg}$ in San Quintín and $1.047 \mathrm{~kg}$ in Vicente Guerrero. In San Quintín, the average specific weight of the compacted solid waste obtained in 24 samples was $229 \mathrm{~kg} / \mathrm{m}^{3}$ with a standard deviation of $53 \mathrm{~kg} / \mathrm{m}$, while the average of uncompacted solid waste in 32 samples was $145 \mathrm{~kg} / \mathrm{m}^{3}$ with a standard deviation of $31 \mathrm{~kg} / \mathrm{m}^{3}$. In Vicente Guerrero was obtained an average specific weight of uncompacted solid waste of $123 \mathrm{~kg} / \mathrm{m}^{3}$ with a standard deviation of $29 \mathrm{~kg} / \mathrm{m}^{3}$ by using 12 samples.

\section{Waste Components Quantification}

In total, 11 samples with a total weight of $883.35 \mathrm{~kg}$ were analyzed, out of which $617.37 \mathrm{~kg}$ corresponded to San Quintín (six samples) and $265.98 \mathrm{~kg}$ to Vicente Guerrero (five samples). Fine wastes and cloth rags were categorized as miscellaneous due to the diversity in their composition. The weights and fractions of every category are summarized in Table 2.

The potentially recyclable waste generated in the state accounts for $42.15 \%$ in San Quintín and 38.69\% in Vicente Guerrero (see Table 3). Disposable diapers, Tetra Pak packaging, batteries and electronic waste can be recyclable, but there is no technology in the region to do it. Therefore, there is no secondary market for these wastes. 
Table 2. Composition of Waste in San Quintín and Vicente Guerrero

\begin{tabular}{|c|c|c|c|c|c|c|}
\hline \multirow[t]{2}{*}{ Classification } & \multicolumn{3}{|c|}{ San Quintín } & \multicolumn{3}{|c|}{ Vicente Guerrero } \\
\hline & Weight & $\%$ Fraction & $\%$ Total & Weight & $\%$ Fraction & $\%$ Total \\
\hline \multicolumn{7}{|l|}{ Organics } \\
\hline Food residuals & 209.44 & $60 \%$ & $34 \%$ & 81.38 & $57 \%$ & $31 \%$ \\
\hline Paper and cardboard & 120.84 & $35 \%$ & $20 \%$ & 47.41 & $33 \%$ & $18 \%$ \\
\hline Yard trimmings & 11.8 & $3 \%$ & $2 \%$ & 14.89 & $10 \%$ & $6 \%$ \\
\hline Wood & 4.62 & $1 \%$ & $1 \%$ & 0.15 & $0 \%$ & $0 \%$ \\
\hline Hard vegetable fiber & 1.8 & $1 \%$ & $0 \%$ & 0 & $0 \%$ & $0 \%$ \\
\hline Leather & 0.22 & $0 \%$ & $0 \%$ & 0.12 & $0 \%$ & $0 \%$ \\
\hline Total & 348.72 & $100.00 \%$ & $56 \%$ & 143.95 & $100.00 \%$ & $54 \%$ \\
\hline \multicolumn{7}{|l|}{ Non-organics } \\
\hline Rigid, film and PET plastics & 91.1 & $45 \%$ & $15 \%$ & 31.78 & $32 \%$ & $12 \%$ \\
\hline Disposable diaper & 48.06 & $24 \%$ & $8 \%$ & 37.34 & $37 \%$ & $14 \%$ \\
\hline Transparent and colored glass & 22.3 & $11 \%$ & $4 \%$ & 16.14 & $16 \%$ & $6 \%$ \\
\hline Tin can & 14.31 & $7 \%$ & $2 \%$ & 5.35 & $5 \%$ & $2 \%$ \\
\hline Expanded polystyrene & 5.28 & $3 \%$ & $1 \%$ & 2.69 & $3 \%$ & $1 \%$ \\
\hline Aluminum & 5.03 & $3 \%$ & $1 \%$ & 1.23 & $1 \%$ & $0 \%$ \\
\hline Tetra Pak packaging & 4.66 & $2 \%$ & $1 \%$ & 2.13 & $2 \%$ & $1 \%$ \\
\hline Construction material & 3.4 & $2 \%$ & $1 \%$ & 0.6 & $1 \%$ & $0 \%$ \\
\hline Crockery and ceramics & 2.19 & $1 \%$ & $0 \%$ & 0.95 & $1 \%$ & $0 \%$ \\
\hline Electronic waste & 2.08 & $1 \%$ & $0 \%$ & 0.98 & $1 \%$ & $0 \%$ \\
\hline Ferrous material & 2.02 & $1 \%$ & $0 \%$ & 0.83 & $1 \%$ & $0 \%$ \\
\hline Batteries & 1.08 & $1 \%$ & $0 \%$ & 0.12 & $0 \%$ & $0 \%$ \\
\hline Total & 201.51 & $100.00 \%$ & $33 \%$ & 100.14 & $100.00 \%$ & $38 \%$ \\
\hline \multicolumn{7}{|l|}{ Miscellaneous } \\
\hline Cloth rags & 45.77 & $68 \%$ & $7 \%$ & 16.3 & $74 \%$ & $6 \%$ \\
\hline Fine waste & 21.37 & $32 \%$ & $3 \%$ & 5.59 & $26 \%$ & $2 \%$ \\
\hline Total & 67.14 & $100.00 \%$ & $11 \%$ & 21.89 & $100.00 \%$ & $8 \%$ \\
\hline Total & 617.37 & & & 265.98 & & \\
\hline
\end{tabular}

Table 3. Percentages of Recyclable Materials in San Quintín and Vicente Guerrero

\begin{tabular}{|c|c|c|c|c|}
\hline \multirow{2}{*}{$\begin{array}{ll}\text { Classification } \\
\text { Recyclables }\end{array}$} & \multicolumn{2}{|c|}{ San Quintín } & \multicolumn{2}{|c|}{ Vicente Guerrero } \\
\hline & Weight & $\%$ Fraction & Weight & $\%$ Fraction \\
\hline Paper and cardboard & 120.84 & $46.44 \%$ & 47.41 & $46.08 \%$ \\
\hline Rigid, film and PET plastic & 91.1 & $35.01 \%$ & 31.78 & $30.89 \%$ \\
\hline Transparent and colored glass & 22.3 & $8.57 \%$ & 16.14 & $15.69 \%$ \\
\hline Tin can & 14.31 & $5.50 \%$ & 5.35 & $5.20 \%$ \\
\hline Aluminum & 5.03 & $1.93 \%$ & 1.23 & $1.20 \%$ \\
\hline Wood & 4.62 & $1.78 \%$ & 0.15 & $0.15 \%$ \\
\hline Ferrous material & 2.02 & $0.78 \%$ & 0.83 & $0.81 \%$ \\
\hline Total & 260.22 & $100.00 \%$ & 102.89 & $100.00 \%$ \\
\hline
\end{tabular}




\section{Ratio Test}

The ratio test was based on the total weight of the samples taken from each community and the results are exposed in Table 4. The comparisons between the main waste components indicate a significant statistical difference only in the fraction corresponding to disposable diapers. The total organic and non-organic portions in both communities do not represent significant statistical differences.

Table 4. Results of the Ratio Test

\begin{tabular}{|c|c|c|}
\hline Type of Waste & Test Statistic (Z) & \multirow{2}{*}{ Critical Value } \\
\hline \hline Food residual & 1.01 & \\
\cline { 1 - 2 } Paper and cardboard & 0.69 & \multirow{2}{*}{ $\pm 2.3267^{*}$} \\
\hline Plastic & 1.11 & \\
\cline { 1 - 2 } Disposable diaper & -2.58 & \\
\hline Cloth rag & 0.80 & \\
\hline Total organics & 0.67 & \\
\hline Total non-organics & -1.38 & \\
\hline
\end{tabular}

*Obtained by interpolation of values in the table "area under the normal curve", for $\alpha=$ 0.02 .

\section{DISCUSSION}

Compaction factor used to calculate the generation in Vicente Guerrero (1.77) is consistent with what it was exposed by the Secretariat of Social Development (SSD)[6]. This indicated that MSW can be hardly compacted to less than half its volume in bulk. Other studies [32, 33] have indicated that the compaction in the waste collection trucks is affected by the density of the wastes and that in developing countries it normally gets volume reduction 1.5:1

The per capita waste generation in these communities is similar to what it was proposed by the SSD [6]. The value for San Quintín is similar to the one for the south of the country $(0.697 \mathrm{~kg})$ and the value for Vicente Guerrero is similar to the one for the north border $(1.048 \mathrm{~kg})$. There are other generation rates reported for Mexico [7, 16, 34] but belong to a study carried out over seven years ago, since then the consumption patterns could have changed.

The per capita generation rates significantly differ between the two communities. According to what it was shown by the Municipal Research and Planning Institute of Ensenada (MRPI) [21], three possible explanations to this fact are: a) the economically active population of Vicente Guerrero is bigger by $9 \%$ than San Quintín's; b) the percentage of workers who get between one and five times the minimum wage is $4.24 \%$ higher in Vicente Guerrero; and c) Vicente Guerrero concentrates the population employed in the majority of the sectors, whereas San Quintín concentrates the largest population in tertiary activities.

Food residuals constitute the main fraction in the two communities. Its percentage is between $32 \%$ and $37 \%$ found by other authors for Mexico [13, 35], but differs from the percentages from other countries such as Macedonia (24\%Hristovsky [4]), Nigeria (12\% -Afon and Afolabi [36]), Bangladesh (62\%-Sujauddin et al. [37]), whose religious, economic, political, and environmental characteristics differ to the studied communities.

The fraction corresponding to textiles in both communities was superior by $1 \%$ proposed for the national mean $[35,38,39]$. However, it is consistent with what it was exposed by Tchobanoglous et al. [23] in middle income countries and with what it was found by Ojeda et al. $[5,40]$ and Ojeda [13] in Mexicali city. This situation may derive from the fact that in these communities is common the sale of second-hand clothes. Due to the quality and low cost, it is more likely to be acquired, as well as disposed of faster.

Only a small fraction of the potential recyclable materials is recovered at the dumpsites. In San Quintín, just aluminum, tin cans, and other ferrous wastes are collected and traded by local waste picker, whereas no material is recovered in Vicente Guerrero. According to Gutierrez [39], it is estimated that in Mexico, the materials recovered to be commercialized afterwards represent $8 \%$ to $12 \%$ out of the total generated.

Despite the contrasts in the generation rates between these two communities, there was only a statistical difference in the fraction corresponding to diapers, whose major proportion was in Vicente Guerrero. This could indicate that the residents from both communities share similar eating habits, but the consumption patterns differ. Regarding the diapers fraction, one could conclude that: a) family composition is not similar between these communities, Vicente Guerrero being the community with the most usage in diapers; and b) a greater purchasing power of Vicente Guerrero's people allow them to acquire this kind of products.

\section{CONCLUSIONS}

The lack of data on the generation and composition of waste in the region prevents the comparison of the data generated in this study. However, this information may serve as a reference for further studies in order to observe the behavior of waste generation over time.

Whenever it is not possible to weigh the waste collection trucks to determine waste generation in a direct manner, the procedure used in Vicente Guerrero can help to obtain an approximation. Trusting common sense or inferring based on data obtained under other contexts (by countries, socioeconomic stratification, among others) may lead to errors in waste estimation and/or seriously affect the credibility of the data generated.

The specific weights of the compacted and uncompacted solid wastes determined in San Quintín $\left(229 \mathrm{~kg} / \mathrm{m}^{3}\right.$ and 145 $\mathrm{kg} / \mathrm{m}^{3}$ ) can be used to: a) verify the efficiency of the waste collection vehicle fleet; b) plan the collection routes; and c) determine the size of waste bins in the households.

Because of the amount of waste generated and discarded by the residents in these rural communities, it is important to invest efforts and provide financial and technical resources in order to develop proper waste management systems that will ultimately improve the quality of life, boost the economy and preserve the environment.

The implementation of waste collection centers, along with waste treatments facilities such as biodigestion or 
composting in these communities, would be very beneficial to reduce the amount of solid waste. It would generate employment opportunities and help reduce the improper disposal of waste and, at the same time, valuable materials could be recovered. All these activities would therefore increase sustainability efforts. If only the organic fraction of waste, which is the largest in both communities, is reduced in the waste generation phase, this would lead to immediate positive impact on the system, such as: a) increased capacity of compaction and reduce the damage to waste collection vehicles; b) lower fuel costs in collecting waste; and c) lower amount of waste deposited in landfills, thus increasing its lifespan.

Joint work between the government and the academic sector may help to generate useful data for the decisionmaking and achieve an appropriate waste management. Integrating the academic sector into governmental projects ensures the sharing of resources and infrastructure, which in turn increases the efficiency of the public resources and raises the academic productivity.

This study is the first one carried out in these communities and its results will be given to the Department of Ecology of the municipality, the Secretariat of Municipal Public Works and the Secretariat for Environmental Protection of the state in order to support the decisionmaking on: a) the building of a sanitary landfill, which will provide service to three delegations of the southern region of the municipality of Ensenada, b) programs oriented to waste reduction and recycling and c) projects on the improvements of waste collection.

\section{ACKNOWLEDGEMENTS}

The authors would like to express their sincere thanks and appreciation to the personnel of the waste collection services of San Quintín and Vicente Guerrero, the chief of the Department of Planning and Environmental Management of the Department of Ecology of the municipality of Ensenada, Biologist Víctor Arenas Lío, and the Deputy Director of Municipal Public Services, Engineer Jorge Aldama, for providing invaluable information and insight into the study. The authors also acknowledge the support received from CONACYT and the Government of Baja California for the financial resources provided for this study through the project FOMIX 77344.

\section{REFERENCES}

[1] O. Buenrostro and G. Bocco, "Solid waste management in municipalities in Mexico: goals and perspectives", Resour. Conserv.Recycl., vol. 39, pp. 251-263, January 2003.

[2] E. Papachristou, H. Hadjianghelou, E. Darakas, K. Alivanis, A. Belou, D. Ioannidou, E. Paraskevopoulou, K. Poulios, A. Koukourikou, N. Kosmidou, and K. Sortikos, "Perspectives for integrated municipal solid waste management in Thessaloniki, Greece", Waste Manage., vol. 29, pp. 1158-1162, March 2009.

[3] G. Gómez, M. Meneses, L. Ballinas, and F. Castells, "Characterization of urban solid waste in Chihuahua, Mexico", Waste Manage., vol. 28, pp. 2465-2471, December 2008.

[4] K. Hristovski, L. Olson, N. Hild, D. Peterson, and S. Burge, "The municipal solid waste system and solid waste characterization at the municipality of Veles, Macedonia", Waste Manage., vol. 27, pp. 1680-1689, December 2007.

[5] S. Ojeda, "El consumo fuente de generación de basura y contaminación", Contaminación y medio ambiente en Baja california, M. Quintero Núñez, Ed., Universidad Autónoma de
Baja California and Miguel Ángel Porrúa, pp. 227-249, January 2006.

[6] Secretariat of Social Development (SSD), "Situación actual en el Manejo de Residuos Sólidos Urbanos (RSU)" 2006.

[7] S. Ojeda-Benítez, C. A. de Vega, and M. E. Ramírez-Barreto, "The potential for recycling household waste: a case study from Mexicali, Mexico", Environ. Urban., vol. 12, pp. 163-173, October 2000.

[8] P. William, Waste Treatment And Disposal. John Wiley \& Sons Inc., 1998

[9] National Institute of Ecology (NIE), Estadísticas e indicadores de inversión sobre residuos sólidos municipales en los principales centros urbanos de México, Mexico City, 1997.

[10] G. Gómez, M. Meneses, L. Ballinas, and F. Castells, "Seasonal characterization of municipal solid waste (MSW) in the city of Chihuahua, Mexico", Waste Manage., vol. 29, pp. 2018-2024, July 2009.

[11] S. Ojeda-Benítez, C. A. Vega, and M. Y. Márquez-Montenegro, "Household solid waste characterization by family socioeconomic profile as unit of analysis", Resour. Conserv.Recycl., vol. 52, pp. 992-999, January 2008.

[12] L. A. L. Márquez, C. C. Jiménez, C. V. Sánchez-Verín, and D. E. T. Cervantes, "Estudio de caracterización de los residuos sólidos urbanos generados en las pequeñas comunidades rurales dentro de un área natural protegida del estado de Chihuahua", EXPO Guadalajara, 2006, pp. 1-14.

[13] S. Ojeda, "Generación de residuos sólidos domésticos y su diferenciación por estrato socioeconómico en la familia mexicalense", Mérida, Yucatán, CEPIS, 2005, pp. 1-10.

[14] O. Buenrostro and I. Israde, "La gestión de los residuos sólidos municipales en la cuenca del Lago de Cuitzeo, México", Rev. Intern. Contam. Ambiental., vol. 19, pp. 161-169, January 2003.

[15] S. Ojeda-Benítez, C. A. D. Vega, and M. E. Ramírez-Barreto, "Characterization and quantification of household solid wastes in a Mexican city", Resour. Conserv. Recycl., vol. 39, pp. 211-222, October 2003.

[16] G. Bernache-Pérez, S. Sánchez-Colón, A. M. Garmendia, A. Dávila-Villarreal, and M. E. Sánchez-Salazar, "Solid waste characterisation study in the Guadalajara Metropolitan Zone, Mexico", Waste Manage. Res., vol. 19, pp. 413-424, October 2001.

[17] O. Buenrostro, G. Bocco, and G. Bernache, "Urban solid waste generation and disposal in Mexico: a case study", Waste Manage. Res., vol. 19, pp. 169-176, April 2001.

[18] J. A. Morales López, "Estrategia de manejo y conservación de recursos hídricos par a la zona de influencia norte de la reserva de la biosfera sian ka'an (RBSK)", Queretaro-Mexico, 2006.

[19] S. Ojolo and A. Bamgboye, "Thermochemical conversion of municipal solid waste to produce fuel and reduce waste" Agricult. Eng. Int. CIGR Ejournal, vol. 7, pp. 1-8, November 2005.

[20] Secretariat of Social Development of the Government of Baja California, SSDE, "Microregiones" 2008.

[21] Municipal Research and Planning Institute of Ensenada, B.C. (MRPI), "Programa de Desarrollo Regional "Región San Quintín". Ensenada, B.C.", 2007.

[22] National Institute of Statistics, Geography, and Data Processing (NISGDP), "Composición de los estratos-AGEB", 2005.

[23] G. Tchobanoglous, H. Theisen, and S. Vigil, Gestión integral de residuos sólidos, Spain: McGraw-Hill, 1994.

[24] CalRecovery, Inc., "Guía para rellenos sanitarios en países en desarrollo", 1997.

[25] E. Gidarakos, G. Havas, and P. Ntzamilis, "Municipal solid waste composition determination supporting the integrated solid waste management system in the island of Crete", Waste Manage., vol. 26, pp. 668-679, April 2006.

[26] Y. Zeng, K. M. Trauth, R. L. Peyton, and S. K. Banerji, "Characterization of solid waste disposed at Columbia Sanitary Landfill in Missouri", Waste Manage. Res., vol. 23, pp. 62-71, February 2005

[27] D. H. F. Liu and B. G. Lipták, Hazardous waste and solid waste, CRC Press, 2000.

[28] D. Liu, B. G. Lipták, and P. A. Bouis, Environmental engineers' handbook, CRC Press, 1997.

[29] Former Secretariat of Trade and Industrial Development (STID), “NMX-AA-015-1985, Método del cuarteo”, 1985.

[30] Former Secretariat of Trade and Industrial Development (STID), "NMX-AA-019-1985, Peso volumétrico "in situ"” 1985. 
[31] Former Secretariat of Trade and Industrial Development (STID), "NMX-AA-022-1985, Selección y cuantificación de subproductos" 1985.

[32] S. Cointreau, "Transfer station design concepts for developing countries", Civil Eng., vol. 6, pp. 1-17, January 2009.

[33] M. Corrales and N. Horton, Residential and industrial (solid) waste disposal support package, 1995. [E-book].

[34] O. Buenrostro Delgado, Los residuos sólidos municipales: perspectivas desde la investigación multidisciplinaria., Universidad Michoacana de San Nicolás de Hidalgo, 2001.

[35] B. E. Jiménez, La contam. ambiental Mex., Mexico City: Limusa, 2002.

[36] A. O. Afon and A. Okewole, "Estimating the quantity of solid waste generation in Oyo, Nigeria", Waste Manage. Res., vol. 25, pp. 371-379, August 2007.
[37] M. Sujauddin, S. Huda, and A. R. Hoque, "Household solid waste characteristics and management in Chittagong, Bangladesh", Waste Manage., vol. 28, pp. 1688-1695, December 2007.

[38] Secretariat of the Environment and Natural Resources (SENR), "Programa nacional para la prevención y gestión integral de los residuos," 2008.

[39] V. G. Avedoy, Diagnóstico básico para la gestión integral de residuos, National Institute of Ecology (NIE), 2006. [E-book].

[40] S. Ojeda Benítez, C. Armijo de Vega, and M. Ramírez-Barreto, "Gestión de residuos sólidos municipales", Una visión de la problemática ambiental de Mexicali y su valle, J. RamírezHernández, Ed., Universidad Autónoma de Baja California, 2006, pp. 137-167.

(C) Taboada-González et al.; Licensee Bentham Open.

This is an open access article licensed under the terms of the Creative Commons Attribution Non-Commercial License (http://creativecommons.org/licenses/by$\mathrm{nc} / 3.0 /$ ) which permits unrestricted, non-commercial use, distribution and reproduction in any medium, provided the work is properly cited. 